\title{
PRILOG UNAPREĐENJU SELEKTOVANJA, STVARANJA I RAZVOJA MENADŽERA U VELIKIM KOMPANIJAMA
}

\author{
Dragana M. Đergović, Lazo M. Kukobat** \\ Visoka brodarska škola akademskih studija u Beogradu \\ Marko D. Andrejic ${ }^{* * *}$ \\ Visoka brodarska škola akademskih studija u Beogradu \\ Univerzitet odbrane u Beogradu, Vojna akademija
}

Drimenom metodološkog pristupa - preciznom analizom poslova, adekvatnom procedurom izbora i razvoja kadrova, kao i permanentnom evaluacijom postignutih rezultata primene selekcionih metoda i obrazovnih programa, potencijalni problemi stvaranja neadekvatne rukovodeće strukture se znatno smanjuju, a stvaraju se pretpostavke za uspešnost procesa upravljanja ljudskim resursima. Načini, organizacioni oblici, metode, tehnike i programi stvaranja, usavršavanja i stručnog osposobljavanja kadrova za menadžerske pozicije su brojni. Njihova efikasnost je različita - očituje se u karijernom napredovanju menadžera i unapređenju kvaliteta poslovanja kompanije. Niz pitanja koja se odnose na proces upravljanja profesionalnim razvojem postojećih i potencijalnih rukovodilaca velikih kompanija, traži odgovore, a neki od njih se analiziraju u ovom radu.

Ključne reči: upravljački zahtevi, menadžerske kompetencije, selekcija, edukacija, razvoj ljudskih resursa, velike kompanije

\section{Uvod}

U poslednjih dvadeset pet godina udeo krupnog biznisa u razmerama svetske ekonomije povećao se više od dva puta. Uticaj velikih preduzeća na poslovnu sredinu intenzivno raste, a njihov razvoj postaje garant stabilnosti nacionalnih i svetske ekonomije. Kao osnovne karakteristike koje razlikuju velike kompanije od ostalih privrednih subjekata (srednjih, malih i mikro preduzeća), mogu se identifikovati sledeće:

- karakteristike strategije kompanije - dugoročnost, orijentacija na sopstvene sposobnosti i kompetencije, visok stepen samostalnosti, unapređene metode i tehnike upravljanja, dominantan položaj na tržištu;

\footnotetext{
* Dr Dragana M. Đergović je docent na Visokoj brodarskoj školi akademskih studija u Beogradu.

** Dr Lazo M. Kukobat je docent na Visokoj brodarskoj školi akademskih studija u Beogradu.

*** Dr Marko D. Andrejić je redovni profesor na na Visokoj brodarskoj školi akademskih studija u Beogradu. Prof. dr Marko D. Andrejić je pukovnik VS u penziji, sa zadržanim zvanjem profesora Vojne akademije Univerziteta odbrane u Beogradu.
} 
Upravljanje sistemima

- kompleksnost poslovnog sistema i sistema upravljanja - vertikalna integracija, razuđena i kombinovana organizaciona struktura, veliki broj nivoa rukovođenja, razgranata struktura korporativnih organa;

- formalizacija i birokratizacija u poslovanju - "široka i duboka" dokumentaciona podrška upravljanju (procedure i standardi, planovi i politike po kojima se odvijaju poslovni procesi);

- resursi i mogućnosti - velika vrednost materijalnih i ljudskih resursa, yelike finansijske mogućnosti za investiranje, inovacije, organizacioni i tehnološki razvoj , relativno nizak nivo pozajmljenih sredstva;

- široka geografska dislociranost delatnosti unutar i izvan granica zemlje;

- internacionalizacija i/ili globalizacija poslovanja - obavljanje poslovne delatnosti van granica matične zemlje i/li u okvirima regionalnog i globalnog tržišta;

- stabilnost - manja zavisnost od kratkoročnih oscilacija na tržištu i promena ekonomskih i drugih faktora;

- jedinstvena organizaciona kultura - sistem zajedničkih korporativnih vrednosti koje prihvata i kojih se u ponašanju pridržavaju menadžment i zaposleni u kompaniji;

- povećani zahtevi prema totalnom kvalitetu - kvalitetu proizvoda i usluga, upravljanja i celokupnog poslovanja prema međunarodnim standardima;

- visok nivo odgovornosti i međusobne saradnje sa državom i društvenom zajednicom;

- imidž i reputacija - visoka prepoznatljivost i ugled u javnosti.

Kompleksnost poslovnog sistema i privredna snaga i moć, determinišu ponašanje velikih kompanija u svim segmentima u kojima ostvaruju svoju ulogu. Brojne su determinante koje ukazuju i potvrđuju njihov značaj za nacionalnu ekonomiju i globalnu privredu:

- vodeće su u delatnosti kojom se bave u zemlji (zemljama) u kojoj posluju;

- podmiruju veliki deo potreba domaćeg tržišta za proizvodima koje proizvode tj. uslugama koje pružaju;

- visoko su efikasne, profitabilne i veliki su budžetski davaoci;

- veliki su investitori u zemlji, regionu i svetu;

- često su sa međunarodno rasprostranjenim aktivnostima, tako da posluju u većem broju zemalja;

- od značaja su za promociju nacionalne privrede i ugleda države širom sveta;

- visoko su poželjni poslodavci, doprinoseći povećanju zaposlenosti u zemlji (zemljama) u kojoj posluju;

- održivim poslovanjem brinu, kako o vlastitoj ekonomskoj održivosti, tako i o zaštiti životne sredine i zdravlja zaposlenih, industrijskoj bezbednosti i socijalnom aspektu poslovanja;

- društveno odgovornim poslovanjem, značajan su donator i sponzor projekata iz oblasti od značaja za lokalnu i širu društvenu zajednicu (u oblastima sporta, kulture, nauke, razvoja mladih talenata);

- poslujući po globalnim standardima i posedujući sertifikate referentnih svetskih institucija o kvalitetu korporativnog upravljanja (IFC standard Međunarodne finansijske korporacije i slično), ne retko su dobitnici brojnih nacionalnih i međunarodnih nagrada i priznanja za uspešnost poslovanja;

- u svrhu prenošenja poslovnog iskustva i inkorporiranja dobre prakse korporativnog upravljanja iz drugih zemalja, često angažuju internacionalni menadžment.

\footnotetext{
${ }^{1}$ Treba biti svestan da, često neviđeni tehnološki razvoj ne prati razvoj humanosti i kulture, a inteligenciju ne prati uvek mudrost, jer mudrost dolazi iz empatije (za čoveka i zajednicu), a ne iz racionalne inteligencije, tako da nije ispravan stav da"sve ima cenu, a ništa vrednost".
} 
Značaj velikih kompanija za privredu zemlje, potrebe prakse, zahtevi vremena i savremeni trendovi zahtevaju da se problemu selekcije, stvaranja, razvoja i podrške upravljačkog kadra srednjeg i najvišeg nivoa, u malim zemljama kao što je Srbija, posveti mnogo više pažnje.

Cilj koji se želi dostići ovim radom jeste da se pruže određena saznanja o ovom važnom području objektivne društvene stvarnosti, zasnovana na teorijskim istraživanjima i praktičnim iskustvima autora ovog rada stečenim kroz rad u velikim poslovnim sistemima.

\section{Zahtevi menadžmentu velikih kompanija}

Izazovi poslovanja poslednjih decenija XX veka, koji su posledica intenzivnog tehničko-tehološkog progresa, procesa globalizacije i delovanja brojnih ekonomskih i neekonomskih faktora internog i eksternog okruženja, uzrokovali su potrebu za značajnim promenama u organizacionim i menadžment strukturama, a pred menadžere kompanija postavili brojne nove zahteve. Dinamične promene u poslovnoj sredini traže brze promene u sistemu, veći kvalitet kadra, nove načine rada i nove adaptabilne organizacione strukture, koje moraju biti upravljane i vođene od strane nove generacije menadžera koji su spremni za probleme koji se pojavljuju. Kontinuelnim sticanjem znanja primenljivih u praksi, moderni menadžment rukovodi kompanijama korišćenjem šansi (prilika) i izbegavanjem pretnji (rizika) iz organizacionog konteksta i spoljašnjeg okruženja, uz primenu situacionog pristupa, odnosno prilagođavanjem konkretnoj situaciji u kojoj zaposleni rade ${ }^{2}$. U kompleksnim velikim poslovnim i upravljačkim sistemima, izazovi su još veći.

Svaki rukovodilac, po pravilu, obavlja određene menadžerske funkcije - planiranje, organizovanje, koordinaciju, vođenje i kontrolu. U realizaciji ovih funkcija, obavljaju se različite grupe poslova - planiranje, postavljanje ciljeva, distribucija zadataka, koordinacija rada, podsticanje, motivisanje, komuniciranje, praćenje, merenje i ocenjivanje postignutih rezultata, razvoj kadrova i organizacije kao celine ${ }^{3}$. Da bi organizacija poslovala uspešno, od menadžera velikih kompanija se zahteva da ispunjavaju različite uloge - nosilaca vizije i strategije, donosilaca odluka, integratora, komunikatora, kreatora pozitivne organizacione klime i kulture, motivatora, balansera konflikata, kontrolora i korektora, ličnosti koja zrači optimizmom i uliva poverenje i veru u uspeh. Preokupacije menadžmenta, danas, rangirane su od povećanja nivoa kvaliteta proizvoda i usluga, unapređenja efektivnosti poslovanja, razvoja novih poslova i uspostavljanja dobrog imidža, dok su opstanak u poslu, povećanje profita, porast tržišnog učešća, "pobeda" nad konkurencijom i uspostavljanje vodeće pozicije na tržištu načini za postizanje primarnih korporativnih ciljeva ${ }^{4}$.

U ostvarivanju svoje specifične uloge, za moderni menadžment velikih sistema važno je preduzetničko ponašanje prema poslu i humanističko ponašanje prema zaposlenima. Sa jedne strane, preduzetnički pristup menadžmenta podrazumeva orijentaciju na rad kompanije kao celine (ne samo dela kojim rukovodi) i fokus na kreiranju promena (ne sa-

\footnotetext{
${ }^{2}$ Đergović, D., Kukobat, L.: Multinacionalna brodska posada i zaposleni u brodarstvu, Tehnika, br. 2/2018, Savez inženjera i tehničara, Beograd, 2018, str. 276-283.

${ }^{3}$ Peter Drucker. The practice of management, W. Heinemann, London, 1955, str. 303-304

${ }^{4}$ Džunić, M.: Uloga menadžmenta i preduzetničkog razvoja u konkurentnosti, 2010, str. 37.
} 
mo na prilagođavanju ili održavanju stanja statusa quo), što za cilj ima iskorišćavanje šansi (a ne iskorišćenja organizacionih resursa) ${ }^{5}$. Sa druge strane, čovek je svesno, misaono, emotivno i racionalno biće, koje ima svoj identitet i integritet, vrednosti i kvalitet, planove i ciljeve, potrebe i interese, život u organizaciji i izvan nje. Ponašanje ljudi (kako u životu, tako i na poslu) se može predvideti, kontrolisati, usmeravati, prilagođavati i menjati na osnovu poverenja i poštovanja, adekvatnim delovanjem uticajnih ličnosti (na poslu - menadžera) ${ }^{6}$. U tom smislu, fokus humanističkog pristupa menadžmenta je na emocionalnoj i duhovnoj inteligenciji (ne samo racionalnoj koja se podrazumeva), kao i na etičkim (moralnim) principima. Emocionalna inteligencija podrazumeva tolerantan stav prema tuđem mišljenju, potrebama i idejama, nezavisnost u stavovima i odlukama o akcijama, prihvatanje odgovornosti i disciplinu, samouverenost, smirenost i empatiju prema zaposlenima, stimulativno delovanje na okolinu, razumevanje, podrška i motivacija na dugi rok itd, a sve u cilju manifestacije specifične pozicije menadžera u organizaciji u pravcu ostvarivanja sinergijskog efekta (ljudskog rada, znanja, iskustva, ponašanja) i organizacionog uspeha. Posedovanje i pridržavanje etičkih principa u upravljanju ljudskim potencijalima označava uspostavljanje sistema korporativnih vrednosti koji je zasnovan na poštenju, pravičnosti, dostojanstvenom tretmanu svakog pojedinca u kolektivu itd, radi usklađivanja individualnih i korporativnih interesa u svrhu opšteg dobra. Dakle, ključ uspeha je u ljudima - u menadžerskom pristupu i ponašanju, koje rezultuje adekvatnom povratnom spregom u ponašanju zaposlenih. U upravljanju organizacijom i promenama, efektivni i efikasni menadžment koristi skup alata za razvoj posebnog okvira razmišljanja i ponašanja - menadžerskog mindseta kojim

1) upravlja pažnjom - ishodom cilja i pravaca akcije, skupom namera i vizijom;

2) upravlja kontekstom - komunikacijom, približavanjem vizije zaposlenima i razvojem bliske saradnje;

3) upravlja poverenjem - prepoznavanjem i balansiranjem ambicija, kompetencija i integriteta zaposlenih;

4) upravlja sobom - sopstvenim sposobnostima i njihovim efektivnim razvojem.

Raznolikost menadžerskih poslova u savremenim uslovima neizvesnosti i iscrpljenih tradicionalnih izvora konkurentnosti, uzrokovala je potrebu za novim strategijskim pristupom upravljanju, koji podrazumeva razvoj i uspostavljanje dve kompatibilne menadžerske strukture na način da su, elementi ponašanja i pristupa upravljanju svake od struktura, potrebni na svim hijerarhijskim novoima i u svim poslovnim funkcijama u organizaciji ${ }^{8}$. U upravljanju složenim poslovnim sistemima, strategijski menadžeri (lideri) na vrhovnom nivou upravljaju vizijom i strategijom rukovodeći ljudskim potencijalima, znanjem, permanentnim učenjem, kao i ukupnim organizacionim ponašanjem u uslovima stalnih promena ${ }^{9}$. Operativni menadžment na nižim hijerarhijskim nivoima efikasno realizuje strateška opredeljenja tekućim planiranjem, balansirajući aktivnosti i usklađujući raspoložive orga-

\footnotetext{
${ }^{5}$ Wickham, P.A.: Strategic Entrerpreneurship, Pearson Education UK, 2004, str. 21.

${ }^{6}$ Andrejić, M., Čabarkapa, O.: Timski rad u vojnim organizacionim sistemima, Vojno delo, Beograd, God. 53., br. 3, 2009, str. 83-108.

${ }^{7}$ Gosling, J., Mintzberg, H.: The Five Minds of a Manager, Harvard Business Review, 2003.

${ }^{8}$ Đergović, D.: Izazovi liderstva XXI veka, FBIM Transactions, Vol. 6, No. 1, MESTE NVO, Poslovni i pravni fakultet Univerziteta Union - Nikola Tesla, Beograd, 2018, str. 24-32.

${ }^{9}$ Kotter, J.P.: Leading Change, Harvard Business School Press, 1996.
} 
nizacione resurse (ljudske, materijalne, energetske, tehnološke, informatičke, finansijske) u pravcu postizanja postavljenih ciljeva. Pred menadžersku strukturu savremenih kompanija, dakle, postavljaju se brojni zahtevi ${ }^{10}$ :

- zahtevi apsorpcionog kapaciteta - sposobnosti da stalno stiču nova znanja i iskustva primenljiva u praksi;

- zahtevi adaptivnog kapaciteta - sposobnosti da se stalno menjaju (prilagođavaju i generišu promene);

- zahtevi liderskog potencijala - sposobnosti da preuzimaju odgovornost za vlastite odluke, na osnovu blagovremeno uočenih izmenjenih trendova (rizika i prilika) i problema koje uzrokuju.

U realnim organizacionim sistemima, menadžment se u sprovođenju svojih zamisli, susreće sa dve različite grupe upravljačkih problema koji zahtevaju i različite načine rešavanja - dobro strukturiranim problemima koji se mogu dovoljno dobro formalno opisati određenim matematičkim modelima, ali i loše strukturiranim problemima koji se ne mogu formalizovati, ili se samo delimično (fragmentirano) formalizuju. U praksi je vrlo teško povući strogu granicu između navedenih grupa problema jer je većina složena i, u određenoj meri, loše stukturirana. Kategorizacija upravljačkih problema po grupama je moguća na osnovu određenih kriterijuma (izvesnosti definisanja funkcija, cilja i skupa polaznih podataka, mogućnosti transformacije podataka), ali uz prisutne rezerve . Uz to, proučavanje formalizovanih i neformalizovanih problema nema puno zajedničkog, što dodatno opterećuje upravljačku praksu. Sledstveno, u pristupu rešavanju složenih problema u kompleksnim poslovnim sistemima, menadžmentu stoje na raspolaganju tri mogućnosti ${ }^{11}$ :

- primena formalizovanih postupaka, tehnika i metoda operacionih istraživanja (različite snage i uopštenosti) za rešavanje dobro strukturiranih problema;

- korišćenje savremenih tehnoloških rešenja za rešavanje delimično strukturiranih problema;

- oslanjanje na integraciju ljudskih potencijala (njihovih specifičnih znanja, iskustva, intuicije, emocija i sposobnosti da identifikuju ključne činioce i iznađu moguće opcije rešenja) sa tehnikama rešavanja standardizovanih problema tj. primena kombinovanog prilaza za rešavanje loše strukturiranih problema.

Kako je složene upravljačke probleme (kojih je u najvećem broju) sve teže rešavati pojedinačno (što je i sve ređe), sve se više radi u grupama - u timovima ${ }^{12}$ kao formalizovanim organizovanim grupama za izvršenje određenog značajnog zadatka koji im je poveren. Timsko rešavanje problema u savremenom poslovnom svetu je nužnost - strogi zahtev vremena u kome živimo. Timskim radom se omogućava maksimalno iskorišćavanje umnih potencijala svakog pojedinca i grupe koja zajednički radi na iznalaženju rešenja, a potrebno vreme se skraćuje za preko $50 \%$ (u poređenju sa sektorskim pristupom) ${ }^{13}$. Kao zajednički rad (a ne izolovan pojedinačni pristup), podrazumeva svrsishodnu stvaralačku konfrontaciju stavova, permanentno konsultovanje i stalno informisanje o rezultatima. Zasniva se na sa-

\footnotetext{
${ }^{10}$ Đergović, D.: Etal. 2018, str. 24-32.

${ }^{11}$ Andrejić, M., Čabarkapa, O.: Etal. 2009, str. 83-108.

${ }^{12}$ Samo zreo čovek može biti član tima, davati timu maksimum i unapređivati svoje sposobnosti zahvaljujući timskom radu i atmosferi.

${ }^{13}$ Jovanović, B.: Uvod u teoriju vojnog rukovođenja, 1984, str. 195-196.
} 
radnji i neposrednoj komunikaciji, bez davanja primata ideja i osporavanja autorstva za ideje njihovim nosiocima. Tim ne priznaje argumente i prioritete sile i autoriteta, već silu argumenata i stavova koji se formiraju konsenzusom, a ne preglasavanjem. Timski rad, sa jedne strane, ne dopušta jaku hijerarhiju i stroge odnose, već je usmeren da, iz članova tima pojedinačno i tima kao celine, izvuče što više kvalitetnog znanja za izvršavanje zadatka i, primenom tog znanja, efikasnije i efektivnije rešavanje problema. Sa druge strane, tim zahteva vođu tima kao team leadera koji, integracijom nastojanja, znanja i učinaka svih članova, doprinosi postizanju maksimalnog sinergijskog efekta. Cilj timskog rada, dakle, jeste dvostruk - u ostvarivanju veće profesionalne efikasnosti i u zadovoljstvu svakog člana tima kako bi se osećao korisnim i aktuelizovanim i, time, kako bi se dostigli vrhunski rezultati pri izvršenju zadatka (rešavanju problema), ostvarenju rezultata i dostizanju ciljeva.

Ako se pođe od činjenice da tim vredi više od pojedinaca, onda je uloga team leadera za preuzimanje ukupne odgovornosti za rezultate rada tima, time veća. Navedeno podrazumeva vođu tima kao team buildera koji, prilikom formiranja tima, primenjuje postulate preduzetničkog i humanističkog pristupa upravljanju - da član tima može biti samo emocionalno zreo čovek koji ima hrabrost i razumevanje za druge, želi međusobnu saradnju i unapređuje svoje sposobnosti shodno timskom duhu i atmosferi tako da daje vrhunski rezultat; koji je kompetentan, pouzdan i poseduje neophodna znanja koja pokrivaju određeni aspekt problema koji je potrebno rešiti; koji je karakterno prihvatljiv (tolerantan, kooperativan, lojalan), vezan odnosom poverenja sa vođom tima (koji mu povratno veruje i delegira ovlašćenja u skladu sa ulogom) i poseduje svest o postojanju različitosti (u karakteru, temperamentu, interesima, stavovima, motivima), ali uz zajednički cilj koji tim ima; drugim rečima, uloga team buildera je da kreira tim kao koheziju različitih „timskih uloga” - istraživača, inovatora, promotera, analitičara, organizatora, savetnika, podržavalaca, finalizatora, integratora, kontrolora i koordinatora. Kombinacijom pozicije i karaktera vođe tima, ispunjavanjem zahteva team leadera i team buildera i korišćenjem moći legitimiteta, stručnosti, ličnog primera, nagrade i prinude ${ }^{14}$, gradi se kredibilitet koji je vezivno tkivo ljudi, koje uliva poverenje celom timu. Kooperativnošću, deljenjem znanja, spremnošću da pomogne i da prihvati pomoć, vođa tima organizuje, distribuira poslove, usmerava i koordinira, informiše i sluša, suzbija konflikte i integriše rad članova, dijagnostifikuje i zajednički rešava probleme ${ }^{15}$. U svojim rukama drži timski uspeh, posredstvom četiri aspekta ponašanja:

1) aspekt rada sa ljudima, kao psihodinamičan, recipročan, uzročan, usmeren i ciljno orijentisan odnos vođe sa članovima tima, je da ih povuče, inspiriše i motiviše, te da se izbori sa vlastitim egom i sujetom;

2) komunikacioni aspekt podrazumeva višesmerno komuniciranje (formalno i neformalno) na relaciji vođe, članova i sa spoljašnjim svetom (unutar i izvan organizacije), koje se zasniva na razvijenoj emocionalnoj inteligenciji ljudi u timu i neminovno je za eliminisanje (ili svođenje na najmanju moguću meru) različitih barijera u radu tima (psiholoških, semantičkih, tehničkih i slično);

3) organizacioni aspekt označava proces kvalitetnog strukturiranja i organizacije rada u timu, kao i kreiranja organizacione klime u kojoj dolazi do izražaja radni potencijal svakog od članova na način da povećava ukupan potencijal tima;

\footnotetext{
${ }^{14}$ Argule, M.: Social interaction, Aldine - Atherfon, Chicago, 1969.

15 Jovanović B.: Upravljanje projektima, Književna zadruga, Beograd, 1990.
} 
4) metodološki aspekt podrazumeva pristup hronološkog odvijanja aktivnosti u rešavanju složenih upravljačkih problema kroz - identifikovanje i kritičku analizu izvora informacija, znanja i mogućih rešenja problema radi donošenja pravilnih zaključaka, njihovo pravilno komponovanje u zaokružene logičke strukture i celine u zavisnosti od faze u životnom ciklusu sistema i pojava i, u epilogu, izbor adekvatnog načina prezentovanja činjenica, znanja i odabranog rešenja ${ }^{16}$.

Šira primena timskog rada u praksi rešavanja složenih organizacionih problema, kao neophodnost modernog poslovanja, podrazumeva ispunjavanje određenih preduslova. Pored stvaranja organizacione kulture i klime za njegovo prihvatanje, „zahvata“ u oblasti organizacione strukture (u nadležnostima, metodima i stilovima rada i upravljanja u pravcu decentralizacije i participativnog upravljanja i izmene odnosa u organizacionoj hijerarhiji u pravcu uvažavanja i saradnje), ključne su obimne „intervencije“ u ljudskim potencijalima (u pogledu selekcije, profesionalnog razvoja, karijernog napredovanja i nagrađivanja, kako eksperata, tako i menadžera na svim nivoima rukovođenja). U budućnosti, vođstvo, moć i uticaj, sve više će pripadati onima koji se pokažu najsposobnijima da reše problem, a ne prema unapred predodređenim i delegiranim pozicijama. Ljudi će se sve manje razlikovati prema rangu, a sve više prema kompetencijama - znanju, obrazovanju, veštinama i sposobnostima da prepoznaju izazove i rešavaju probleme.

\section{Poželjne kompetencije menadžera u velikim kompanijama}

U savremenim uslovima dinamičnog i nepredvidivog poslovanja, sve su strožiji zahtevi za menadžere i menadžerske poslove. Za uspešno upravljanje kompanijama potrebne su brojne menadžerske sposobnosti, znanja, veštine, navike, stavovi, iskustva i osobine ličnosti. U osnovi moći i uticaja preduzetničkog menadžmenta, u kompanijama svih veličina i delatnosti, je širok spektar kompetencija koje se neprekidno unapređuju - doživotnim učenjem i praktičnim radom. U pitanju je trajan proces ličnog i profesionalnog razvoja, koji zavisi od individualne inicijative, ali i posvećenosti ulaganju u kadrove same kompanije. Mišljenje da se dobar menadžer rađa danas je prevaziđeno, a sve više se uviđa da fokus mora biti na permanentnom razvoju.

Od rukovodioca velikih kompanija se danas očekuje da su u stanju da, na bazi uzročno-posledičnih veza i odnosa, trendova pojava i procesa, stvaraju viziju poslovanja, kreiraju strategiju i operacionalizuju je komuniciranjem sa zaposlenima i usklađivanjem različitih poslova. Navedeno podrazumeva sposobnost blagovremene anticipacije izazova, brzo uočavanje i dijagnostifikovanje problema, široko i duboko sagledavanje mogućih rešenja. Drugim rečima, moderni menadžment bi trebalo da bude proaktivan, kreativan i fleksibilan, da ima veliki lični kredibilitet i autoritet i suštinsku moć, na način da integriše operativne i liderske aktivnosti.

Polazeći od uloge menadžera u savremenom poslovnom svetu, te činjenice da je u fokusu interaktivan odnos menadžmenta i zaposlenih u konkretnoj situaciji u kojoj se nalaze, ključne karakteristike koje menadžere čine uspešnim (kao rezultanta ispunjenosti zahteva apsorpcionog i adaptivnog kapaciteta i liderskog potencijala) su:

1) personalni kapacitet koji poseduju - individualne karakteristike, adekvatna znanja, potrebne veštine i specifični atributi ličnosti;

\footnotetext{
${ }^{16}$ Andrejić, M., Čabarkapa, O.: Etal. 2009, str. 83-108.
} 
Upravljanje sistemima

2) međuljudski odnosi koje grade - zasnovani na edukativnoj, informacionoj, komunikacionoj i motivacionoj ulozi menadžera i otelotvoreni u pozitivnoj razmeni sa zaposlenima u čijoj je osnovi dvosmerna komunikacija i stimulativna organizaciona kultura i klima za promene;

3) vođenje promena koje sprovode - kreiranje strateške promene i realizacija kroz operativne programe;

4) fokusiranost na rezultat - odgovornost za dostizanje strateških ciljeva, balansiranjem ličnih i korporativnih, kratkoročnih i dugoročnih ciljeva i interesa ${ }^{17}$.

Uspešni menadžeri velikih kompanija savremenog doba u složenim poslovnim sistemima su generalisti - široko obrazovani ljudi, koji svoja različita znanja stalno inoviraju, razvijaju, proširuju i primenjuju u praksi. Pri tome, nije neophodno da poznaju sva stručna područja rada zaposlenih u organizaciji, ali je neophodno da razumeju suštinu, sagledavaju celinu i poseduju smisao za rad sa ljudima. Studije o prirodi menadžerskog posla u savremenim uslovima ukazuju da uspešni menadžer u proseku $1 / 3$ radnog vremena troši na komuniciranje sa zaposlenima, $1 / 3$ na saradnju sa subjektima izvan kompanije, dok $1 / 3$ ostaje za obavljanje svih ostalih upravljačkih funkcija ${ }^{18}$.

Posedovanje adekvatnih poslovnih i inovativnih, tehničkih, humanističkih i koncepcijskih, funkcionalnih, sistemskih i situacionih, stručnih, opštih i specifičnih znanja koja su primenljiva u radu, predstavlja potreban, ali ne i dovoljan uslov uspešnog rukovođenja. Savremena teorija sve više govori, a praksa se sve više oslanja i potvrđuje neophodnost posedovanja relevantnih sposobnosti i veština za socio-psihološko, analitičko, logičko i kompleksno promišljanje u rešavanju različitih problema, kao i za razumevanje osnova biznisa, okruženja (poslovnog, državnog, međunarodnog), kompanija i timova. Za menadžere velikih kompanija ključne su:

- upravljačke sposobnosti - sposobnosti koordinacije rasta i razvoja kompanije kojom rukovode;

- organizacione sposobnosti - sposobnosti usklađivanja raspoloživih resursa sa realizacijom ciljeva;

- rukovodilačke sposobnosti - sposobnosti komuniciranja, koordinacije i usmeravanja aktivnosti;

- konceptualne i kognitivne veštine - veštine dijagnostifikovanja problema;

- analitičke veštine - veštine korišćenja upravljačkih tehnika neophodnih za rešavanje problema;

- veštine odlučivanja - "selekcije pravca akcije" u odabiru najboljeg rešenja problema;

- komunikacione (interpersonalne) veštine - uspostavljanja dvosmerne komunikacije sa zaposlenima;

- tehničke i informatičke veštine - veštine korišćenja alata savremenog poslovanja;

- "soft skills" - veštine suptilnog uticaja i pridobijanja ljudi u organizaciji.

Uspešna primena stečenih znanja, sposobnosti i veština determinisana je poželjnim osobinama ličnosti menadžera koje se odnose na temperament, interese i karakter. Pod njima se podrazumeva:

- orijentisanost prema kompaniji i grupi (timu), a manje prema samom sebi i ličnim preokupacijama;

\footnotetext{
${ }^{17}$ Sajfert, Z., Adžić, S., Cvijanović, J.M.: Korporativno liderstvo, Tehnički fakultet, Zrenjanin, 2012.

${ }^{18}$ Gosling, J., Mintzberg, H.: Etal. 2003.
} 
- široka interesovanja, postojani i usklađeni interesi; dela);

- izraženi moralni (etički) kvaliteti i lični integritet (visoka konzistentnost između reči i

- emocionalna inteligencija i socijalno usmerena motivacija za moć (svesnost, solidarnost, kolektivizam);

- vizionarstvo i vođstvo, energičnost i hrabrost;

- sistematičnost, upornost, posvećenost i lojalnost organizaciji;

- inicijativnost i inovativnost u pronalaženju novih načina u rešavanju upravljačkih problema;

- spremnost da se preuzme rizik i odgovornost za donete odluke i preduzete akcije;

- osećaj za „prave stvari u pravo vreme“ i za „pravu meru“ u zahtevima;

- samopouzdanje, entuzijazam, želja za dokazivanjem i uspehom;

- visok stepen frustracione tolerancije, fleksibilnost i adaptabilnost, uz širok raspon percepcije;

- prepoznatljiv stil upravljanja sa naglašenim crtama participativnog odlučivanja i stvaranja suštinskog autoriteta;

- talenat, harizma i mnogo toga još ${ }^{19}$.

S' obzirom na to da svaka osobina ličnosti nije podjednako prisutna kod svakog pojedinca, dominantna osobina (za koju se može reći da je potvrđena u kompaniji) je ono što menadžere razlikuje, te ih i preporučuje za konkretnu poziciju u upravljačkoj hijerarhiji složenih poslovnih sistema kao - vođu" (menadžera koji je sposoban da kreira i upravlja ključnim procesima i poslovima u kompaniji), "donosioca odluka" (menadžera koji poseduje sposobnost "selekcije pravca akcije"), "integratora" (menadžera čija je primarna sposobnost komunikacija), "analitičara" (menadžera izrazitih analitičko-informatičkih sposobnosti) i/ili "kreatora atmosfere" (menadžera sa dominantnim socio-psihološkim sposobnostima).

Rezultanta ponašanja modernog menadžmenta je u kreiranju sistema vrednosti - opštih stavova i moralnih načela, koja čine polaznu osnovu za uspešan rad kompanije i odredišnu tačku formirane organizacione kulture:

- da je čovek krajnja mera svih vrednosti;

- da je pristup menadžera (posvećenost i odgovornost, poštovanje i uvažavanje, komunikacija i međusobno poverenje, razmena i deljenje znanja, pohvale i kritike) presudan za odnos zaposlenih prema radu i njihovo radno ponašanje i uspešnost u svim fazama životnog ciklusa organizacije;

- da je za organizacioni uspeh ključan kvalitetan izbor i stalna edukacija menadžera i zaposlenih;

- da se vođstvo ličnim autoritetom zaslužuje stalnim nadograđivanjem, savesnim i predanim radom i uzornim ličnim ponašanjem menadžera.

Kako bi unapređenje personalnog kapaciteta menadžerskog kadra u velikim kompanijama bio kontinuirani proces, upravljanje ljudskim resursima (selektovanje i razvoj) mora biti strateško područje delovanja kompanije.

\footnotetext{
${ }^{19}$ Andrejić, M., Čabarkapa, O.: Etal. 2009, str. 83-108
} 


\section{Problemi selektovanja i razvoja menadžera u velikim kompanijama}

Uloga procesa profesionalne selekcije je da se, na osnovu relevantnih informacija o kandidatima dobijenih primenom odgovarajućih metoda i instrumenata, prognozira njihova buduća radna uspešnost, kako bi se izabrali najkvalitetniji kadrovi, sa potencijalno najboljim poslovnim rezultatima. Uloga procesa razvoja selektovanog menadžerskog kadra je da edukacijom, putem različitih programa obrazovanja i obuka, stalno unapređuju postojeća i stiču nova neophodna znanja, sposobnosti i veštine, koje će im pomoći da se efikasno izbore sa potencijalnim izazovima (šansama ili pretnjama iz bližeg ili daljeg okruženja), na način da doprinose sveukupnom organizacionom razvoju (unapređivanjem radnih učinaka, efikasnosti rada i efektivnosti poslovanja).

$U$ vremenu brzih i stalnih promena uslova privređivanja, uspeh kompanija je, u najvećoj meri, uslovljen sposobnošću kontinuiranog prilagođavanja okruženju, u čijoj je osnovi pristup upravljanju ljudskim resursima. Adekvatnim upravljanjem kadrovima - planiranjem potreba, dobrom pripremom (analizom posla i zahteva), primenom objektivnih kriterijuma i odgovarajućih tehnika selekcije i alokacije ${ }^{20}$, pravilnim opredeljivanjem i sprovođenjem na efikasan način programa obrazovanja i obuke, posao postavljenja „pravog čoveka na pravu poziciju“ je znatno olakšan, a proces selekcije i razvoja kadrova u kompaniji uspešan. Nasuprot, pogrešnom selekcijom i odsustvom potrebnog znanja i sposobnosti, kreativnosti i odgovornosti, iskustva i lošim rejtingom upravljačke strukture, dolazi do neracionalnog trošenja ljudskih resursa (kako menadžera, tako i zaposlenih), što rezultira lošim poslovnim odlukama i neefikasnim poslovanjem kompanije. Poredeći četiri moguća ishoda u procesu izbora i razvoja menadžera (opredeljivanje za uspešnog, odbijanje uspešnog, odbijanje neuspešnog i opredeljivanje za neuspešnog kandidata), najpogubnija odluka za budućnost kompanije je odabir (selekcioni i/ili razvojni) nekvalitetnih kandidata/kadrova za menadžerske pozicije. Troškovi pogrešnih odluka za svaku kompaniju su ogromni - kako neposredni troškovi sprovođenja postupka selekcije, troškovi socijalizacije i izdaci za realizaciju obrazovnih programa, tako (još u većoj meri) indirektni troškovi i štetne posledice lošeg izbora. U pitanju je, ne samo manji radni učinak, nego i moguće negativno delovanje na motivaciju, moral i zadovoljstvo zaposlenih, a ne mogu se isključiti ni potencijalni nesporazumi i konflikti na relaciji menadžer - zaposleni ${ }^{21}$.

U velikim kompanijama, posao selektovanja, stvaranja, i razvoja odgovarajućeg rukovodećeg kadra još je teži. Razlog tome je u složenosti poslovne strukture (po širini i dubini), odnosno u kompleksnosti, dinamičnosti i visokoj međuzavisnosti poslova koji se obavljaju i brojnosti zahteva koji se pred menadžment ovih kompanija postavljaju, a koji se odnose na sledeće ${ }^{22}$ :

- veličina organizacije može prouzrokovati brojne probleme - lanac komande je ekstremno dugačak, donošenje odluka je usporeno, a zamisli menadžera mogu biti blokirane postojanjem velikog broja "tačaka provere" i učesnika u usvajanju strateških oprede-

\footnotetext{
${ }^{20}$ Majstorović, A., Andrejić, M.: Modern Management in the Defense System, Management, No. 47-48, Year XIII, April 2008, p. 19-26.

${ }^{21}$ Kulić, Ž., Vasić, M.: Menadžment ljudskih resursa, Banja Luka, 2007, str. 105.

${ }^{22}$ Gardner, John W.: Leadership in Large-Scale Organized Systems. The Leader's Companion J. Thomas Wren. New York, New York: Free Press, 1995, str. 298-299.
} 
ljenja koja, ne retko, nisu razumljiva za sve donosioce odluka; sa druge strane, kod zaposlenih se može razviti osećaj "anonimne osobe" koja nema nikakvu mogućnost uticaja na poslovanje, te ličnu odgovornost za ostvarene rezultate;

- menadžeri velikih kompanija, sledstveno, moraju posebnu pažnju posvetiti ljudima, uspostavljajući i razvijajući najmanje tri kanala komunikacije - prema donosiocima strateških odluka koje bi trebalo ubediti u valjanost svojih zamisli, prema nižim menadžerskim strukturama koje bi trebalo ohrabriti na participaciju zaposlenih u odlučivanju, kao i prema zaposlenima kod kojih bi trebalo razviti osećaj pripadnosti kompaniji u kojoj rade;

- veličina organizacije podrazumeva inovativne poslovne modele - uspostavljanje, operacionalizaciju i sprovođenje large-scale koncepta upravljanja organizacionim sistemom široke i duboke poslovne strukture, kao i kreiranje različitosti u uslovima izrazite kompleksnosti poslovnog ambijenta i sistema;

- velikim kompanijama su, sledstveno, potrebni menadžeri koji, bez obzira na deo kojim rukovode, imaju sposobnost sagledavanja poslovanja i upravljanja kompanijom u celini $^{23}$, na način da poznaju, ne samo složene organizacione modele funkcionisanja segmenta poslovanja kojim rukovode, već celokupnost procesa koje kompanija obavlja;

- drugim rečima, velikim kompanijama su potrebni strategijski orijentisani menadžeri (menadžeri koji poseduju liderski potencijal) i u poslovima koje u manjim kompanijama može obavljati operativni menadžment, koji su istovremeno generalisti (širokih i opštih znanja), kreativci (ljudi od ideja i zamisli) i operativci (ljudi sa sposobnošću da ih operativno realizuju).

U smislu iznetog, adekvatna selekcija i razvoj menadžerskog kadra u kompleksnim poslovnim sistemima predstavlja ozbiljan posao. Zbog složenosti parametara čija se povezanost mora utvrditi (zahteva posla i individualnih kvalifikacija i razvojnih potencijala, individualnog ponašanja i radne uspešnosti, sposobnosti i spremnosti za doživotno učenje i primenu naučenog u praksi), kao i potrebnog angažovanja i izdataka, rezultati procesa mogu biti daleko od očekivanih i poželjnih, sa dalekosežnim posledicama. Razloga tome je mnogo:

- objektivna selekcija i razvoj menadžerskog kadra predstavlja rešavanje višekriterijumskog problema ${ }^{24}$ sa velikim brojem složenih kriterijuma različitog nivoa značajnosti, jer je radno ponašanje samo delimično predodređeno karakteristikama pojedinaca (osobinama tipa ličnosti i sposobnostima), a u velikoj meri zavisi i od delovanja određenih situacionih faktora, odnosno uslovljeno je mnoštvom objektivno-subjektivnih faktora i interakcija individualnih karakteristika i organizacione stvarnosti;

- kompleksnost i raznolikost radnog ponašanja se, sledstveno, ne može optimalno predvideti jer, pored postojanja merljivih razlika između ljudi koje su značajne u determinisanju radne uspešnosti, postoje i teško „uhvatljivi“ elementi u proceni;

- i pored široko rasprostranjenih savremenih metoda i tehnika koje kompanije primenjuju u selekciji menadžerskih kadrova (referenci, intervjua i brojnih psiholoških testova različitih vrsta - sposobnosti, ličnosti, inteligencije, interesovanja, znanja, kreativnosti, sposobnosti sticanja veština itd), procena budućeg ponašanja u radu i radnog učinka na menadžerskim pozicijama nikada nije u potpunosti pouzdana;

\footnotetext{
${ }^{23}$ Sve je deo celine i celina delova, sve je „deo igre i igra delova“, sve se menja - samo su promene stalne.

${ }^{24}$ Andrejić, M.: Primena višekriterijumske - multiatributne asignacije na odabranom primeru, Vojnotehnički Glasnik, Beograd, God. 42., br.2, 1994, str. 44 - 52
} 
Upravljanje sistemima

- prognostička valjanost pojedinačnih selekcionih metoda je, sledstveno, različita (različiti je stepen tačnosti procene buduće radne uspešnosti kandidata u obavljanju menadžerskog posla), na način da primena niti jedne od njih ne garantuje apsolutnu uspešnost izbora (ma koliko bile objektivne i detaljne), jer se selekcijski rezultati nikada ne mogu smatrati do kraja relevantnim (različit je samo stepen minimiziranja grešaka u odlučivanju);

- proces razvojnog obrazovanja i obuka menadžera (obuhvat kadrova, raznovrsnost i kvalitet obrazovnih metoda i programa, transfer naučenog u praksi) zavisi od brojnih faktora (ponašanja polaznika, motivacije za učenje i primene načela učenja), koji se formiraju pod uticajem interakcije brojnih spoljnih sila (okruženja i radne sredine) i unutrašnjih sila (rezultata, učesnika i organizacionog sistema), čije delovanje nije uvek stimulativno;

- i pored primene objektivnih kriterijuma (opravdanosti i pouzdanosti) i različitih alata od strane eksperata za ljudske resurse (kao predlagača), na odabir menadžera u procesu selekcije i razvoja, u velikoj meri, utiče i subjektivnost procene vrhovnog menadžmenta (kao donosilaca konačne odluke);

- iako je zadatak eksperata za ljudske resurse predlaganje, a vrhovnog menadžmenta kompanije upravljanje ljudskim resursima, uspešnog procesa nema bez aktivnog odnosa svakog pojedinca (kandidata za menadžersku poziciju u procesu selekcije i izabranog menadžera za proces razvoja);

- iako je mnogo razloga koji ukazuju na važnost sprovođenja evaluacije primenjenih selekcionih metoda i obrazovnih programa, mnoge kompanije ovom procesu ne ukazuju dovoljno pažnje, smatrajući da je završetkom selekcije menadžera, odnosno njihove obuke, završen i proces selekcije, odnosno razvoja;

- i pored činjenice da dobro upravljanje ljudskim resursima zahteva značajno korporativno ulaganje novca, vremena i stručnog rada u zavisnosti od složenosti, nivoa i važnosti posla za koji se menadžer bira, odnosno u zavisnosti od obuhvata, strukture i kvaliteta programa obrazovanja i obuka koje organizuje (direktni troškovi primene različitih metoda selekcije i programa razvoja, kao i angažmana stručnjaka su znatni), u kompanijama to nije uvek prepoznato u finansijskim planovima poslovanja;

- sa druge strane, o indirektnim troškovima pogrešnog odabira menadžera u selekcionom i razvojnom procesu, odnosno o budućim problemima i potencijalnim poslovnim gubicima zbog loših odluka (koji su daleko veći od direktnih troškova procesa upravljanja ljudskim resursima), često se na vreme ne razmišlja, jer nisu lako procenjivi i tek su kasnije vidljivi.

Efekti procesa selekcije i razvoja menadžerskog kadra značajno su ograničeni ukoliko nisu ukomponovani sa ostalim aktivnostima procesa upravljanja ljudskim resursima (planiranjem ljudskih resursa i analizom posla, prevashodno), kao i ukoliko se ovaj proces ne odvija uz primenu odgovarajućeg metodološkog pristupa. lako se problemi u potpunosti ne mogu eliminisati, organizovan pristup u procesu stvaranja menadžerske strukture je $u$ osnovi dobrog upravljanja i uspešnog poslovanja svake kompanije. U smislu iznetog, u velikim poslovnim sistemima potrebno je primeniti metodološki pristup, koji uspostavlja pretpostavke uspešnosti procesa selekcije i razvoja menadžerskog kadra, a odnosi se na:

1) preciznu sistematizaciju pozicija menadžera - opis poslova i specifikaciju zahteva;

2) sistemsku proceduru - izbora (regrutovanja i selekcije) i razvoja menadžera;

3) permanentnu evaluaciju postignutih rezultata primene selekcionih metoda i obrazovnih programa. 
Prva pretpostavka uspešnosti procesa selekcije i razvoja menadžerske strukture je u obezbeđivanju dobre analize posla, kako bi se na zadovoljavajući način definisali poslovi koje je potrebno obavljati i uslove koje je potrebno ispuniti za odrađenu menadžersku poziciju, kroz:

- opis posla - koji obuhvata aktivnosti konkretne menadžerske pozicije, potrebne uslove rada, dodeljena ovlašćenja i odgovornosti;

- specifikaciju posla - koja obuhvata zahteve same menadžerske pozicije (opšte uslove kvalifikovanosti i stručnosti, radno iskustvo, psiho-fizičke sposobnosti, veštine i dodatne uslove), kao i zahteve koji se odnose na celu organizaciju (poželjne osobine ličnosti, socijalne kompetencije i slično).

Menadžerska pozicija, pored sistematizacijom propisanih zahteva, podrazumeva i zainteresovanost i motivisanost svakog pojedinca za posao za koji se kandiduje, sposobnost i spremnost za doživotno učenje.

Druga pretpostavka uspešnosti je sistemska procedura selekcije i razvoja menadžera, koji obuhvata:

- detaljnu pripremu - identifikovanje potreba kompanije za određenim kadrovima, skrining "nasleđenog" stanja i procenu potencijala postojeće menadžerske strukture;

- definisanje plana selekcije i razvoja menadžera - utvrđivanje ključnih područja radne uspešnosti i standarda koji je opredeljuju (pravih, merljivih i pouzdanih kriterijuma), načina pronalaženja potencijalnih kandidata i procene njihovih znanja i drugih kompetencija, rezultata rada i ponašanja koje su ostvarili na prethodnim pozicijama i organizacijama (kao garancija da će valjano obavljati poslove koji im se dodele), kvalitetnih parametara i adekvatnih metoda provere kandidata (selekcije od strane eksperata organizacionog dela zaduženog za ljudske resurse), kao i programa dalje edukacije i treninga;

- realizaciju plana selekcije i razvoja menadžera - primenu izabranih kriterijuma, načina, metoda i tehnika selekcije (standardizovano ocenjivanje kandidata i njihovih kvaliteta), kao i programa obrazovanja i obuka menadžerskog kadra izabranog za dalju edukaciju;

- sistematsko vrednovanje - procenu uticaja selekcije i razvoja menadžerskih kadrova na poslovanje;

- uspostavljanje održivog impulsa stvaranju menadžerske strukture - obezbeđivanje sredstava za stalno i rastuće investiranje u razvoj - u menadžere različitih nivoa sa liderskim potencijalom, kadrove sa menadžerskim sposobnostima i obećavajućim polaznim predispozicijama $^{25}$.

Treća pretpostavka uspešnosti procesa selekcije i razvoja menadžerske strukture je permanentna evaluacija (sistematsko procenjivanje i vrednovanje) postignutih rezultata primene selekcionih metoda i obrazovnih programa, kako bi se došlo do saznanja o njihovoj efikasnosti - uticaju na poboljšanje ponašanja i radnih učinaka, učenje i primenu usvojenih znanja i stečenih veština, radne uspešnosti i konačnog uspeha organizacije. Kvalitetna procena selekcijskih rezultata se zasniva na podacima o direktnim troškovima izbora (angažovanja stručnjaka i primenjenih metoda selekcije) i ostvarenim poboljšanjima poslovnih rezultata. $U$ vrednovanju obrazovnih programa, koristi se četiri kriterijuma reakcija polaznika (njihovo mišljenje, zadovoljstvo, kritike, sugestije i povratne informacije

\footnotetext{
${ }^{25}$ The Institute of Public Administration in Canada (IPAC): Leading Large-Scale Leadership Development, IPAC Conference Survey, Edmonton, Canada, 2011
} 
Upravljanje sistemima

o kvalitetu obrazovnog procesa - uslovima, nastavnicima, sadržaju, metodama i tehnikama, aplikativnosti na posao), nivo naučenog (stečenog) novog znanja i veština, promena radnog ponašanja koja se odnosi na primenu naučenog u praksi, kao i rezultati koji se tiču ostvarenih poboljšanja poslovanja po osnovu realizovanih obrazovnih programa (radnog učinka, profita i slično ${ }^{26}$. Navedena saznanja su neophodna radi sagledavanja dobrih i loših strana selekcionog i razvojnog procesa kako bi se, već prilikom sledećeg izbora, odnosno organizovanja obuke, izbegle štetne pojave kroz primenu:

1) unapređenih metoda selekcije - bolje strukturiranih intervjua koje sprovodi veći broj obučenih intervjuera, naknadne provere kandidata od strane vrhunski kompetentnih stručnjaka za psihološke testove, standardizovanog ocenjivanja kandidata i njihovih kvaliteta i slično;

2) novina u obrazovnom procesu - u obuhvatu kadrova, primenjenim metodama (individualnim i grupnim), strukturi i sadržaju programa (na poslu i izvan njega), kvalitetu predavača i trenera.

lako se primenom metodološkog pristupa (ispunjavanjem pretpostavki uspešnosti) u složenim poslovnim sistemima smanjuje verovatnoća pogrešnog izbora kandidata i polaznika obuke za menadžerske pozicije, prisutni su i rizici neadekvatnog selektovanja i razvoja, sa neizbežnim posledicama po kvalitet poslovanja.

\section{Proces stvaranja menadžera u velikim kompanijama}

Današnje poslovno okruženje podrazumeva stalnu prilagođenost organizacionih sistema lokalnim i globalnim promenama, što zahteva uspostavljanje adekvatnih načina razvoja menadžerskog kadra. Na njihov način razmišljanja, delovanja i ponašanja (u najvećoj meri) utiču one promene koje se istovremeno događaju u svim delovima savremenog sveta i koje uzrokuju širenje jaza između sve većih zahteva posla i aktuelnih znanja na tržištu rada, sve veći jaz između dinamike poslovanja i dinamike razvoja sistema obrazovanja, jaza između radnog učinka i emocionalnog zadovoljstva zaposlenih, sve brže zastarevanje postojećih i sve viši nivo zahtevanog novostvorenog znanja, zajedno namećući potrebu stalnog inoviranja kompetencija menadžera edukacijom.

Kako za uspeh organizacionog razvoja ključnu ulogu imaju menadžeri, tako se razvoju menadžera u najuspešnijim organizacijama na svetu prilazi krajnje ozbiljno, pri čemu kompanije ne žale ni truda, ni novca, ni vremena da bi znanja i sposobnosti svojih menadžera doveli na zavidan nivo. Razlozi i ciljevi menadžerskog razvoja su brojni - od sprečavanja „zastarevanja“ i oblikovanja menadžera za rešavanje kompleksnih poslovnih problema u promenljivoj okolini i povećanja ukupne menadžerske uspešnosti i većeg radnog zadovoljstva, preko stvaranja poluge za kreiranje organizacione kulture i uspostavljanja održivog impulsa razvoju i jačanju konkurentske sposobnosti na tržištu, do osiguranja dostupnosti i spremnosti menadžera za popunjavanje sadašnjih i budućih pozicija višeg menadžmenta.

Kako bi se procesom stvaranja menadžera obezbedili preduslovi za realizaciju poslovnih ciljeva i značajno povećao kvalitet poslovanja, u velikim kompanijama upravljanje

${ }^{26}$ Kulić, Ž., Vasić, M: Etal. 2007, str. 281-282 
selekcijom i razvojem menadžerskog kadra je potrebno sprovesti na način koji podrazumeva:

- jedinstveni sistem upravljanja selekcijom i razvojem menadžera - koji obuhvata analizu sadašnjih i budućih potreba, finansiranje, organizovanje i sprovođenje programa selekcije, stručnog usavršavanja i osposobljavanja u skladu sa potrebama postojećih, inoviranih i novih poslovnih procesa u kompaniji, kao i ulogu nadležne stručne organizacione celine za ljudske resurse kao nosioca celokupnog procesa ${ }^{27}$;

- koherentnost aktivnosti upravljanja kadrovima - personalno-psihološkim faktorima, faktorima personalno-radne međuzavisnosti, faktorima komunikacije, kao i faktorima organizacije i kulture ${ }^{28}$

- univerzalni pristup ulaganja u selekciju i razvoj menadžera - koji je u poželjnim kompetencijama, zalaganju i rezultatima rada, stručnosti i profesionalnosti, posvećenosti i lojalnosti, kreativnosti i inovativnosti, uz uvažavanje ličnih preferencija svakog pojedinca;

- ciljnu usmerenost procesa - koja se odnosi na podizanje nivoa kompetentnosti, formiranje "rezervne garniture" menadžera za odgovarajuće više pozicije i razvoj kadrova sa obećavajućim predispozicijama;

- odgovarajući kvalitet i strukturu programa stvaranja menadžera - koji su organizaciono i konceptualno usklađeni sa savremenom teorijom i praksom sticanja menadžerskih i liderskih kompetencija;

- realizaciju ciljeva profesionalnog razvoja - koji se odnose na zadovoljenje potreba kompanije za visokokvalitetnim menadžerima različitih profila, radi dostizanja visokih individualnih postignuća i maksimiziranja zajedničkog rezultata, u pravcu ostvarivanja korporativnih ciljeva rasta i razvoja.

Profesionalni razvoj menadžerskog kadra realizuje se edukacijom na poslu i izvan njega (uobičajeno i izvan kompanije). U praksi, najčešće tehnike obrazovanja menadžera na poslu su rotacija (kretanje kroz organizaciju radi sticanja znanja o upravljanju celom organizaciji i njenim organizacionim delovima) i mentorstvo (individualno osposobljavanje menadžera za buduću rukovodeću poziciju, prenošenjem znanja i iskustva od strane mentora-menadžera na toj poziciji). Profesionalni razvoj menadžera izvan radnog mesta, sprovodi se organizovanim programima obrazovanja i obuka, koji se koncipiraju u zavisnosti od polaznika i cilja, sa jasnim pravima, obavezama i odgovornostima kompanije i zaposlenog. Svaki od programa usmeren je na razvijanje. specifičnih menadžerskih znanja i sposobnosti, u zavisnosti od nivoa menadžmenta kome pripadaju Sledstveno, tematske oblasti razvojnih programa menadžera su različite - od poslovnog razmišljanja, planiranja i postizanja ciljeva, odgovornosti i donošenja odluka, efektivne i efikasne komunikacije i timskog rada, do ličnih preferencija koje su (istovremeno) ključne za razvoj menadžerskih sposobnosti.

Generalno, najzastupljeniji su trening programi koji se sprovode od strane relevantnih agencija za razvoj ljudskih rasursa, kao informativni seminari - koji imaju za cilj da promovišu važnost i potrebu za kontinuiranim razvojem menadžera i da privuku što vi-

\footnotetext{
${ }^{27}$ Đergović, D.: Specifičnosti liderstva u velikim kompanijama u Srbiji, Fakultet za poslovne studije, Beograd, 2014, str. 134-142

${ }^{28}$ Đergović, D., Kukobat, L.: Etal. 2018, str. 278
} 
še polaznika; osnovni kursevi - koji su namenjeni mlađim menadžerima sa malo (ili nimalo) radnog iskustva (te na neki način čine vezu između fakultetskog obrazovanja i početka menadžerske karijere u kompaniji), te obuhvataju opšte tematske oblasti (upravljanje ljudskim resursima, finansijama, projektima i slično); kursevi za obrazovanje rukovodećeg kadra - koji su prilagođeni potrebama iskusnijih menadžera prvog i srednjeg nivoa menadžmenta, te se zasnivaju na razmeni iskustava primenom brainstorming metode; programi za obrazovanje rukovodećeg kadra - koji su namenjeni mlađim polaznicima sa radnim iskustvom, korišćenjem studija slučaja, simulacionih modela.

Programi usavršavanja i stručnog osposobljavanja menadžera, na primeru velike domaće kompanije sa međunarodnim poslovanjem ${ }^{29}$, detaljno su razrađeni i permanentno se organizuju. U zavisnosti od realizatora programa (eksternih ili internih izvora), najprisutniji su programi obrazovnih institucija i renomiranih konsultantskih agencija (mada pojedine programe mogu sprovoditi i zaposleni kompanije, koji su kompetentni za tematsku oblast).

Programi obrazovanja su univerzalni programi koji su namenjeni vrhovnom menadžmentu kompanija, radi razvijanja kompetencija za poslovanje u globalnim okvirima. Realizuju se poslediplomskim obrazovanjem na univerzitetima, u formi MBA (Master of Business Administration)ili EMBA (Executive Master of Business Administration) specijalističkih studija.

Programi stručnog osposobljavanja su specijalistički programi obuke menadžera, koji su usmereni na razvoj menadžerskih i liderskih potencijala postojećeg rukovodećeg kadra na različitim organizacionim nivoima (programi za linijske, menadžere srednjeg i najvišeg nivoa), koji sukcesivno pohađaju pojedinačne programe i, shodno rezultatima, razvijaju karijeru raspoređivanjem na više menadžerske pozicije. Realizuju se, uglavnom, od strane specijalizovanih konsultantskih agencija za ljudske resurse. Korporativni treninzi, obuke i seminari su programi koji se odnose na sve menadžere u kompaniji, a tematski su usmereni na razvoj ključnih kompetencija prema potrebi posla (Tabela 1).

Program kadrovske rezerve je program obuke kadrova za menadžerske pozicije koji se, u zavisnosti od kategorije učesnika, strukturira kao program formiranja strateške, odnosno operativne kadrovske rezerve. Strateška kadrovska rezerva uključuje profesionalni razvoj menadžerskog kadra viših hijerarhijskih nivoa i potencijala, koji se priprema za više rukovodeće pozicije, ili za popunjavanje upražnjenih mesta, ili za zamenu postojećeg menadžerskog kadra, u vremenskom periodu od jedne do pet godina. Operativna kadrovska rezerva se odnosi na profesionalni razvoj perspektivnih kadrova iz redova zaposlenih, koji se pripremaju za ciljne pozicije čije je popunjavanje od posebnog značaja za kvalitet poslovanja kompanije, u trenutku ukazane potrebe. Program se pokreće sa ciljem privlačenja i očuvanja najboljih kadrova (kroz razvoj lojalnosti zaposlenih i imidža kompanije kao poželjnog poslodavca na tržištu radne snage), kao i kako bi se, u svakom trenutku, raspolagalo zaposlenima koji su prošli odabir i obuku, te poseduju znanja, iskustva, veštine i sposobnosti da preuzmu odgovarajuće menadžerske pozicije.

\footnotetext{
${ }^{29}$ Đergović, D.: Specifičnosti liderstva u velikim kompanijama u Srbiji, Fakultet za poslovne studije, Beograd, 2014, str. 134-142.
} 
Tabela 1 - Katalog korporativnih treninga

\begin{tabular}{|l|l|}
\hline \multicolumn{1}{|c|}{ NAZIV PROGRAMA } & \multicolumn{1}{c|}{ RAZVOJ KLJUČNE KOMPETENCIJE } \\
\hline Ekonomija za (ne)ekonomiste & Analitičko razmišljanje \\
\hline Postavljanje ciljeva & Strateško planiranje \\
\hline Povećanje produktivnosti i motivacija & Razvoj potencijala zaposlenih \\
\hline Upravljanje vremenom i delegiranje poslova & Upravljanje radnim zadacima (pojedinaca i timova) \\
\hline Upravljanje stresom & Uspostavljanje pozitivne organizacione klime \\
\hline Veštine davanja i dobijanja feedback-a & Razvoj međusobne saradnje \\
\hline Poslovna strategija & Efektivno upravljanje poslovnim procesima \\
\hline Situaciono liderstvo & Primena odgovarajućeg stila liderstva \\
\hline Lični potencijal, odgovornost i asertivnost & Upravljanje ličnim potencijalom i sobom \\
\hline Izgradnja tima i timske uloge & Upravljanje timskim potencijalom \\
\hline Coucing trening programi & Upravljanje razvojnim potencijalima saradnika \\
\hline Veštine efektivne komunikacije & Upravljanje komunikacijom \\
\hline Veštine prezentovanja i javni nastup & Razvoj asertivnosti \\
\hline Donošenje odluka & Sistemski pristup u poslovnom odlučivanju \\
\hline Upravljanje konfliktima & Upotreba konflikata kao prilike \\
\hline Upravljanje promenama & Strateški proaktivni pristup upravljanju \\
\hline Balanced Scorecard (BSC) metod & Usklađivanje strateških i operativnih ciljeva \\
\hline Upravljanje projektima & Razvoj projektne organizacije \\
\hline Menadžerski stilovi, uloge i veštine & Razvoj sposobnosti menadžera \\
\hline Veštine pregovaranja & Upravljanje pregovorima \\
\hline Veštine facilitacije & Upravljanje različitostima \\
\hline
\end{tabular}

Izvor: Đergović, D.: Specifičnosti liderstva u velikim kompanijama u Srbiji 2014, str. 140

Programi rotacije kadrova su programi stručnog osposobljavanja menadžera u kompanijama koje posluju na međunarodnom planu. Podrazumevaju upućivanje najboljih polaznika prethodnih programa (menadžera različitih organizacionih nivoa) u inostrane delove matične kompanije sa ciljem razvoja globalnog potencijala (formiranja menadžerskih timova kompanije na globalnom nivou), te uspostavljanja efektivnog i jednoobraznog sistema upravljanja u svim segmentima delatnosti i svim teritorijalno dislociranim afilijacijama. Rotacija (privremeni transferi), kao jedan od svetski prepoznatih vidova profesionalnog razvoja globalnih lidera, doprinosi razmeni iskustva i prakse, održavanju jedinstvene korporativne kulture i iznalaženju zajedničkih rešenja za unapređenje kvaliteta poslovanja. Pored rukovodećeg kadra, u program mogu biti uključeni i zaposleni čije zanimanje zahteva dodatna znanja i veštine, i/ili stručnjaci izrazitih upravljačkih sposobnosti, kao i zaposleni koji su uključeni u formiranje "rezervne garniture" kadrova za ciljne rukovodeće pozicije i koji pokazuju visoke rezultate procene trenutnog nivoa kompetencija i visok nivo potencijala za razvoj. Program se realizuje kroz selekciju na osnovu individualnih pokazatelja uspešnosti rada i organizacionu podršku odlasku odabranih kadrova u inostranstvo - na praksu (u trajanju do šest meseci), ili na ostanak i rad (od jedne do tri godine).

Specifični programi selekcije i stručnog osposobljavanja su razvojno orijentisani trening programi mlađih kadrova, usmereni na profesionalni razvoj za menadžerske pozicije uz rad. Sprovode se po mentorskom principu (coucing, feedback i feedforward), sa ciljem da se prepozna, selektuje i, na najbolji način, iskoristi potencijal najboljih mladih ljudi sistematskim razvojem njihovih stručnih i upravljačkih znanja i sposobnosti, povećanjem kompe- 
tentnosti i kvalifikacija, na osnovu prihvatanja korporativnih vrednosti i upravljanjem motivacijom i karijerom. Realizuju se organizovanjem obuka, učešćem na stručnim konferencijama i stažiranjem, ali i prisustvom na kulturnim, sportskim i drugim događajima radi razvijanja osećaja pripadnosti i lojalnosti kompaniji. Uobičajeno traju do dve godine, uz godišnju evaluaciju ispunjenosti individualnih planova razvoja i, uz dobre rezultate, mogućnosti daljeg razvoja karijere uključivanjem u ostale programe stručnog osposobljavanja.

Rezultati procesa stvaranja menadžerske strukture mogu biti različiti po kompanijama, u zavisnosti od ostvarenog ${ }^{30}$ :

- ličnog razvoja - poboljšanja radnog učinka na postojećem radnom mestu;

- razvoja karijere - unapređenja učinka na budućem radnom mestu na višoj hijerarhijskoj poziciji;

- sistema menadžmenta učinaka - povećanja organizacione sposobnosti i kapaciteta organizacionog učinka;

- organizacionog razvoja - unapređenja iskorišćenosti ljudskih potencijala, poboljšanja organizacione kulture, povećanja produktivnosti, organizacione efikasnosti i konkurentske prednosti na tržištu.

Sledstveno, sastavni deo procesa „izgradnje“ menadžera, što je i uobičajena praksa u velikim kompanijama, čini praćenje i merenje efekata ulaganja u obrazovanje i obuku kadrova za rukovodeće pozicije. Efekti se mogu posmatrati sa dva aspekta:

1) organizacionog aspekta - na osnovu pokazatelja povećanja kvaliteta poslovanja (produktivnosti, ekonomičnosti, rentabilnost, efikasnosti i efektivnosti);

2) personalnog aspekta - na osnovu pokazatelja radne uspešnosti i razvoja karijere menadžera i kadrova sa obećavajućim rukovodećim predispozicijama.

Povećenje kvaliteta poslovanja organizacije, kao rezultanta dobrog korporativnog upravljanja (prevashodno upravljanja ljudskim resursima, adekvatnom selekcijom, stvaranjem i razvojem menadžerskog kadra), danas se prati primenom različitih matematičkih metoda i modela. Tradicionalne metode se zasnivaju na utvrđivanju ključnih pokazatelja performansi kompanije, koje se odnose na perspektivu finansija, korisnika, poslovnih procesa i obuke i razvoja (BSC - Balance Scorecared i drugi modeli). Nove metode integrišu interne instrumente ocene - indikatore uspešnosti poslovanja koji mere ostvarivanje strateških korporativnih ciljeva (povećanje ukupne vrednosti kompanije) i strateškog budžeta (prihode, rashode i profit kompanije), sa eksternim instrumentima ocene pokazateljima koji mere finansijsko poslovanje (finansijsko stanje i vrednost kompanije) i nefinansijske efekte (ekonomske, ekološke i socijalne performanse) ${ }^{31}$.

Razvoj karijere menadžera se prati u skladu sa ostvarenim napretkom u dostizanju željenih kompetencija obrazovanjem i obukama (na osnovu postavljenih ciljeva sadržanih $u$ individualnim planovima razvoja) i procenjene radne uspešnosti za nivo dve do tri rukovodeće pozicije iznad postojeće. Definisanjem aktivnosti u procesu stručnog osposobljavanja, kao i dinamike sprovođenja u toku godine, efekti ulaganja u stvaranje kadrova za rukovodeće pozicije mere se pokazateljima - motivisanosti za dostizanje planiranog, sistematičnosti u ciljnoj orijentaciji, fokusiranosti na ciljeve ličnog razvoja, sinhronizova-

\footnotetext{
${ }^{30}$ Kulić, Ž., Vasić, M: Etal. 2007, str. 299.

${ }^{31}$ Mešalkin, V.P., Kravčenko, K.A.: Upravljanje velikom kompanijom, , Fakultet tehničkih nauka, Novi Sad, 2011, str. 153-170.
} 
nosti individualnih i korporativnih interesa i angažovanosti u pohađanju planiranih obuka. U cilju pravilnog usmeravanja karijere menadžera, pored procene buduće radne uspešnosti na višoj poziciji, nužno je poznavati i dinamiku vremenskog sazrevanja menadžerskog kadra i planski i organizovano raditi na sistemu napredovanja, kako bi ostvarena radna uspešnost, po postavljanju na višu poziciju, odgovarala procenjenoj.

Karijerno napredovanje menadžera (Tabela 2) zahteva strategijski pristup, zasnovan na sagledavanju kapaciteta, definisanju ciljeva i analizi karakteristika okruženja (situacije), na osnovu sledećih postulata ${ }^{32}$ :

- nema sigurnog napredovanja ako se preskoči neki od ciljeva;

- svaki od ciljeva zahteva odgovarajuće lične kapacitete i odgovarajuće karakteristike okruženja;

- u prvoj polovini karijere više pažnje je potrebno posvetiti osposobljavanju (ne napredovanju);

- rezultati su stalni i treba ih stalno davati da bi se stekla mogućnost napredovanja u karijeri;

- u napredovanju bi se trebalo opredeliti za rezultate za kojima postoji potreba, prilike i uslovi;

- od kvaliteta rezultata zavisi i kvalitet napredovanja;

- za svaki novi stepen u karijeri potrebna su nova znanja, sposobnosti i rezultati rada.

U poslovnoj praksi, za uspešan razvoj karijere menadžera važna je promena pozicije unutar kompanije i između kompanija. U velikim poslovnim sistemima kretanje po hijerarhiji (vertikalno) i horizontalno je, sa jedne strane, lakše (usled veličine i raspoloživosti različitih menadžerskih pozicija) ali, sa druge strane, teže (usled većih zahteva menadžerskih pozicija i jače konkurencije za istu poziciju). Provera ličnih kapaciteta u obavljanju novih dužnosti, uobičajeno, intenzivnija je u prvoj polovini karijere (u prvih deset godina staža), tako da se početnicima savetuje promena ne manje od tri, ali i ne više od pet kompanija (pozicija). Intenzivnija fluktuacija se ne preporučuje, jer ne donosi koristi ni menadžeru, ni organizaciji. Razlog je u činjenici da je menadžerima na početku karijere potrebno najmanje dve godine za upoznavanje sa karakteristikama organizacione sredine i za evaluiranje vlastitih potencijala kroz rezultate rada.

Tabela 2 - Strategijski pristup razvoja i karijernog napredovanja menadžera

\begin{tabular}{|l|l|l||}
\hline \multicolumn{1}{|c|}{ KAPACITETI } & \multicolumn{1}{c|}{ CILjEVI } & \multicolumn{1}{c||}{ OKRUŽENjE } \\
\hline \hline Perspektivnost & Životni standard & Prihvatljivost \\
\hline Stav prema društvu & Prihodi & Veze \\
\hline Poslovnost & Položaj & Položajni autoritet \\
\hline Stav prema ljudima & Ugled & Lični autoritet \\
\hline Stav prema poslu & Rezultati & Stručni autoritet \\
\hline Kreativnost & Rad & Prilike \\
\hline Vrednoća & Znanje & Uslovi - mogućnosti \\
\hline Inteligencija & Osposobljavanje & Potrebe \\
\hline Stav prema samom sebi & Zdravlje & Radni i životni uslovi \\
\hline \hline
\end{tabular}

Izvor: Andrejić, M., Čabarkapa, O.: Timski rad u sistemu odbrane, 2009, str. 36

\footnotetext{
${ }^{32}$ Andrejić, M., Čabarkapa, O.: Etal.2009, str. 36.
} 


\section{Zaključak}

Izazovi koje promene u XXI veku nameću velikim kompanijama (posebno internacionalnim kompanijama koje deluju na teritoriji više država), kod malih i nesvrstanih zemalja kao što je Srbija, iniciraju potrebu razmišljanja o globalnom upravljanju i neprekidno proučavanje, praćenje, analizovanje i unapređivanje sistema korporativnog upravljanja. Poslovanje u savremenom svetu podrazumeva spremnost kompanija i njihovih rukovodećih struktura na "suočavanje" sa izrazito složenim uslovima turbulentnog globalnog okruženja, čijim se menjanjem upravlja. Organizacione promene nisu moguće bez promene ljudi u organizaciji - u njihovom znanju i iskustvu, sposobnostima i veštinama, osobinama i stavovima. U osnovi procesa promena je adekvatno upravljanje ljudskim resursima - selekcija i profesionalni razvoj, kako menadžera, tako i zaposlenih sa obećavajućim početnim upravljačkim ili ekspertskim predispozicijama. U cilju unapređenja (racionalizacije i optimizacije) odlučivanja vezanog za selektovanje, stvaranje i razvoj menadžerskog kadra, savremena nauka nudi dosta metoda (različite snage i generalnosti), tehnika i softvera kojima se, uz kombinaciju sa iskustvom iz operativne prakse, smanjuju subjektivizam i cena procesa donošenja odluka, a povećava njihova objektivnost.

$S$ obzirom na to da je cilj "izgradnje" adekvatne menadžerske strukture u velikim kompanijama povećanje kvaliteta ukupnog poslovanja, rezultate procesa upravljanja ljudskim resursima i efekte ulaganja u selekciju i profesionalni razvoj (obrazovanje i obuke) menadžera, trebalo bi tumačiti u kontekstu sledećih okolnosti:

- raspoloživosti sredstva za finansiranje procesa - ulaganje u selekciju i profesionalni razvoj menadžera trebalo bi da bude stalno i rastuće, kako bi se obezbedio održivi impuls poboljšanju poslovne uspešnosti;

- obuhvata menadžerskog kadra i zaposlenih sa potencijalom za preuzimanje rukovodećih pozicija - uključenost menadžera u profesionalni razvoj trebalo bi da bude što šira, kako bi u karijerno napredovanje bili involvirani oni kadrovi koji imaju najbolju procenjenu uspešnost na višoj poziciji;

- stepena preuzimanja rukovodećih pozicija od strane kadrova u čiji se profesionalni razvoj ulaže - angažovanost na menadžerskim pozicijama, koja odražava efikasnost ulaganja u menadžerski kadar, trebalo bi da bude što veća (u suprotnom, predstavlja korektivni faktor procesa);

- odnosa svakog pojedinca prema vlastitom razvoju i napredovanju u karijeri - bez dobrovoljnosti i spremnosti na celoživotno učenje, lični i profesionalni razvoj, ambicije i želje, nema ni uspeha.

Spoznaja o postojanju međuzavisnosti između ulaganja u menadžerske kadrove i poboljšanja poslovnih rezultata, važan je signal kompanijama za projektovanje intenzivnijeg rasta i povećanje apsolutnog iznosa investiranja u ljudske resurse, kako bi se dostigli planirani ciljevi poslovanja i neutralisala moguća ograničenja. Međutim, važno je naglasiti da je teško izolovano proceniti efekte selekcionog i obrazovnog procesa na uspeh organizacije, sobzirom na to da na unapređenje organizacionih performansi utiče i sprovođenja drugih korporativnih aktivnosti (poboljšanje kvaliteta, sniženja cena proizvoda i/ili usluga, dobar marketing i slično), kao i očekivano i/ili neočekivano delovanja eksternih faktora (poboljšanje kupovne moći, pogoršan položaj neposrednih konkurenata na tržištu i slično). 
Pri rešavanju problema selekcije, stvaranja i razvoja menadžerskog kadra za potrebe velikih kompanija, izuzetno je značajno (posebno za male zemlje kao što je Srbija) da se, već tokom osnovnih akademskih studija, prepoznaju ljudi (razvijenim sistemom skautinga na državnom nivou) sa širokim misaonim obuhvatom i duhovnom inteligencijom, koji su patriotski vaspitavani i osvešćeni, te koji su u stanju da usmeravaju društvenu energiju u željenom pravcu adekvatnom edukacijom (uticaj adekvatnog socijalnog potencijala), kako bi (kasnije) dostigli maksimum genetski uslovljenog potencijala.

Sobzirom na porast obima multinacionalnog poslovanja i uloge globalnih kompanija, nužno je respektovati uticaj nacionalne kulture na formiranje organizacionih struktura (posebno menadžerskih) velikih poslovnih sistema. U skladu sa značajem koji imaju za zemlje u kojima posluju, upravljački kadar u ovim kompanijama je potrebno tretirati orijentacijom na životni ciklus, na tok kretanja u prostoru, vremenu i situaciji, kao i orijentacijom na kvalitet proizvoda i usluga koje pružaju korisnicima i na dobrobit koju kreiraju za širu društvenu zajednici.

Kombinovanjem primene dostupnih naučnih saznanja o globalnom upravljanju i lokalnom delovanju i praktičnih iskustava, moguće je znatno unaprediti selektovanje, stvaranje i razvoj menadžera u velikim kompanijama, štiteći vlastite nacionalne interese.

\section{Literatura}

[1] Ђерговић, Д., Кукобат, Л.: Мултинационална бродска посада и запослени у бродарству, Техника, бр. 2/2018, Савез инжењера и техничара, Београд, 2018, стр. 276-278.

[2] Peter Drucker. The practice of management, W. Heinemann, London, 1955, str. 303-304.

[3] Џунић, М.: Улога менаимента и предузетничког развоја у конкурентности, 2010, стр. 37.

[4] Wickham, P.A.: Strategic Entrerpreneurship, Pearson Education UK, 2004, str. 21.

[5] Андрејић, М., Чабаркапа, О.: Тимски рад у војним организационим системима, Војно дело, Београд, Год. 53., бр. 3, 2009, стр. 83-108.

[6] Gosling, J., Mintzberg, H.: The Five Minds of a Manager, Harvard Business Review, 2003.

[7] Ђерговић, Д.: Изазови лидерства XXI века, FBIM Transactions, Vol. 6, No. 1, MESTE NVO, Пословни и правни фракултет Универзитета Унион - Никола Тесла, Београд, 2018, стр. 24-32.

[8] Kotter, J.P.: Leading Change, Harvard Business School Press, 1996.

[9] Јовановић, Б.: Увод у теорију војног руковођења, 1984, стр. 195-196.

[10] Argule, M.: Social interaction, Aldine - Atherfon, Chicago, 1969.

[11] Јовановић Б.: Управљање пројектима, Књижевна задруга, Београд, 1990.

[12] Сајферт, 3., Аџић, С., Цвијановић, Ј.М.: Корпоративно лидерство, Технички факултет, Зрењанин, 2012.

[13] Мајсторовић, А., Андрејић, М.: Modern Management in the Defense System, Management, No. 47-48, Year XIII, April 2008, p. 19-26.

[14] Кулић, Ж., Васић, М.: Меначмент људских ресурса, Бања Лука, 2007, стр. 105, 281-282, 299.

[15] Gardner, John W.: Leadership in Large-Scale Organized Systems. The Leader's Companion J. Thomas Wren. New York, New York: Free Press, 1995, str. 298-299.

[16] Андрејић, М.: Примена вишекритеријумске - мултиатрибутне асигнације на одабраном примеру, Војнотехнички Гласник, Београд, Год. 42., бр. 2, 1994, стр. 44-52.

[17] The Institute of Public Administration in Canada (IPAC): Leading Large-Scale Leadership Development, IPAC Conference Survey, Edmonton, Canada, 2011.

[18] Ђерговић, Д.: Специфричности лидерства у великим компанијама у Србији, Факултет за пословне студије, Београд, 2014, стр. 134-142.

[19] Мешалкин, В.П., Кравченко, К.А.: Управљање великом компанијом, Факултет техничких наука, Нови Сад, 2011, стр. 153-170. 